\title{
MODEL LATIHAN IMAGERY TERHADAP KETEPATAN FLOATING SERVICE ATLET VOLI PANTAI NTB
}

\section{Johan Irmansyah; Muhammad Ridwan Lubis \& Andi Gilang Permadi Dosen FPOK IKIP Mataram \\ Email: joevoley@gmail.com}

\begin{abstract}
Abstrak; Floating Service adalah jenis servis dimana jalannya bola dari hasil pukulan servis itu tidak mengandung putaran, dengan kata lain bola berjalan mengapung atau mengambang. Dengan demikian tingkat kesulitan dalam melakukan floating service lebih tinggi jika dibandingkan dengan servis normal. Selain membutuhkan teknik servis yang baik, dibutuhkan pula mental dan kepercayaan diri seorang atlet, hal ini berhubungan erat antara imagery dan penampilan atlet dalam olahraga. Penelitian ini bertujuan untuk menghasilkan sebuah model latihan Imagery terhadap Ketepatan Floating Service pada Atlet Voli Pantai NTB. Penelitian ini menggunakan metode penelitian dan pengembangan atau yang sering disebut research and development yang mana digunakan untuk menghasilkan sebuah produk yang diinginkan. Penelitian $R \& D$ ini menggunakan 10 langkah sesuai dengan pendapat Sugiyono. yaitu: (1) Studi pendahuluan (analisis kebutuhan), (2) perencanaan (tujuan penelitian, dana, waktu, prosedur penelitian, berbagai bentuk partisipasi, (3) mengembangkan produk awal (perencanaan draft awal produk), (4) ujicoba awal (mencoba draft produk ke wilayah dan subjek yang terbatas), (5) revisi untuk menyusun produk utama, (6) uji coba lapangan utama (uji coba ke wilayah dan subjek yang lebih luas), (7) revisi untuk menyusun produk operasional, (8) uji coba produk operasional (uji efektif produk), (9) revisi produk final (revisi produk yang efektif), dan (10) diseminasi dan implementasi produk hasil pengembangan. Penelitian ini dilakukan pada UKM Bola Voli IKIP Mataram untuk uji coba skala kecil, Klub Bola Voli Lombok Tengah untuk skala besar, dan Klub Voli Pantai NTB untuk uji efektifitas produk akhir. Pengumpulan data berupa panduan analisis kebutuhan yang dikemas dalam wawancara, kuesioner obeservasi sistematik pada uji skala kecil dan skala besar dan lembar penilaian atlet. Teknik analisis data untuk validitas instrument menggunakan formula Aiken's $V$ (content validity coefficient)/ $V=\Sigma s /[n(c-1)]$, dan uji produk menggunakan rumus $P=f / n \times(100 \%)$ dengan standar klasifikasi kelayakan. Berdasarkan dari hasil penelitian yaitu studi pendahuluan, uji skala kecil dan skala besar yang telah dilakukan dengan percobaaan floating service dinyatakan bahwa penilaian para ahli terhadap model latihan imagery untuk meningkatkan ketepatan floating service dikatakan 'layak' untuk diterapkan di lapangan.
\end{abstract}

Kata kunci: Pengembangan Model, Latihan Imagery, Floating Service.

\section{Pendahuluan}

Voli pantai adalah variasi dari bola voli yang dimainkan di atas pasir. Pada dasarnya, sebagian besar peraturan dan teknik- teknik yang terdapat pada permainan bola voli pantai sama dengan permainan bola voli indoor. Menurut (Ma'mun dan Subroto, 2001:54) dikemukakan bahwa keterampilan teknik permainan bola voli dapat di bagi dalam enam bagian: 1) sikap penjagaan dan cara pergerakan, 2) passing dan umpan (passing bawah, passing atas dan umpan), 3) servis (servis bawah, servis dari samping dan servis atas), 4) spike/smash, 5) bendungan (blocking),
6) penerimaan bola (receive). Teknik dasar yang menjadi fokus atau objek dalam penelitian ini adalah servis atas, yang dimana salah satu teknik dalam melakukan servis atas adalah dengan floating service (servis mengambang).

Floating Service merupakan salah satu servis yang dikembangkan dikarenakan kesukaran lawan dalam menerima servis terletak pada sifat jalannya bola yang mengapung, serta jalannya bola pada lintasan lurus, kecepatan yang tidak teratur, bola sering melayang ke kiri dan ke kanan. Yunus (1992: 69) dikatakan bahwa Floating Service adalah 
jenis servis dimana jalannya bola dari hasil pukulan servis itu tidak mengandung putaran, dengan kata lain bola berjalan mengapung atau mengambang. Dengan demikian tingkat kesulitan dalam melakukan floating service lebih tinggi jika dibandingkan dengan servis normal. Selain membutuhkan teknik servis yang baik, dibutuhkan pula mental dan kepercayaan diri seorang atlet. Sukadiyanto, (2011:44) mengemukakan bahwa, ada empat aspek latihan yang perlu diperhatikan dan dilatih secara seksama oleh atlet, yaitu 1) latihan fisik, 2) latihan teknik, 3) latihan taktik dan 4) latihan mental (psikologis).

Dalam penelitian ini, peneliti tertarik terhadap aspek psikologis dari atlet, karena aspek ini masih kurang diperhatikan oleh beberapa pelatih atau Pembina olahraga. Seringkali terdengar bahwa kekalahan dari atlet karena faktor psikologis mereka, tetapi jarang sekali kita mendengar komentar pelatih bahwa seorang atlet dapat memenangkan pertandingan disebabkan oleh aspek psikologis, seakan aspek psikologis merupakan sebuah kesalahan dan menjadi alasan non teknis sebagai pertahanan diri dari kekalahan yang dialami seorang atlet.

Setelah peneliti melakukan studi pendahuluan di lapangan menggunakan metode observasi dan wawancara, terdapat permasalahan mendasar yang harus segera mendapatkan solusi berupa pengembangan model latihan imagery untuk meningkatkan ketepatan floating service, permasalahannya adalah: 1) Program latihan dasar yang khusus untuk melakukan floating sevice masih belum maksimal dilakukan oleh para atlet karena metode latihan yang konstan dan alokasi waktu yang kurang efisien dalam penerapan latihan, 2) Program latihan yang disusun oleh pelatih masih didominasi pada aspek latihan fisik, teknik dan taktik daripada mengeksplorasi latihan fundamental dari floating service yang merupakan serangan utama dalam permainan bola voli, 3) Metode latihan imagery yang difokuskan untuk meningkatkan aspek psikologis atlet masih belum diterapkan oleh para pelatih, dan 4) Proses evaluasi yang dilakukan pelatih masih mendeskripsikan secara umum kemampuan para atlet tanpa menelaah latihan-latihan fundamental yang bisa meningkatkan motivasi atlet dalam melakukan latihan maupun pertandingan.

Hubungannya dengan penelitian ini adalah, peneliti ingin memberikan sebuah metode latihan psikologis untuk atlet voli pantai NTB agar mampu meningkatkan ketepatan floating service, model latihannya berupa pengembangan latihan imagery. Morris (2005: 48) mengemukakan bahwa adanya hubungan erat antara imagery dan penampilan atlet dalam olahraga. Untuk dapat berprestasi harus ada kepercayaan diri atlet bahwa ia sanggup dan mampu untuk mencapai prestasi yang diinginkan. Sedangkan dalam perspektif imagery ada suatu perbedaan yang dirasakan seseorang antara imagery secara tidak nyata (internal imagery) dan imagery secara nyata (eksternal imagery). Dalam eksternal imagery, seseorang dapat melihat dirinya sendiri melalui media di luar dirinya seperti melihat dari video/alat rekam, sedangkan internal imagery, seseorang berimajinasi seakan nyata melakukan suatu keterampilan. Jadi latihan imagery akan bekerja efektif ketika kinestetik imagery bersamaan dengan perspektif imagery (internal dan eksternal).

Pengembangan model latihan imagery untuk meningkatkan ketepatan floating service ini bertujuan untuk menghasilkan kelayakan sebuah model latihan Imagery terhadap Ketepatan Floating Service pada Atlet Voli Pantai NTB.

\section{Tinjauan Pustaka}

\section{Hakikat Imagery}

Istilah imagery, visualisasi, dan latihan mental telah digunakan secara beragantian oleh para peneliti, psikolog olahraga, pelatih dan atlet untuk menggambarkan teknik pelatihan mental yang kuat. Pada awal perkembangan latihan mental merupakan istilah yang dipakai untuk menggambarkan teknik latihan imagery, tetapi istilah ini hanya merujuk pada gambaran umum dari strategi berlatih dengan modalitas sensorik atau kognitif yang digunakan (Taylor \& Wilson, 2005:1). Holmes \& Collins (2001:1) mengatakan bahwa dewasa ini sebagian besar praktisi olahraga telah menggunakan latihan mental imagery yang menggambarkan teknik latihan mental terstruktur untuk menciptakan suatu kinerja olahraga yang optimal. Menurut Hardy, Jones \& Gould (1996:1), biasanya 
beberapa atlet menggunakan latihan imagery tidak terstruktur yang dilakukan spontan guna mencapai tujuan tertentu, mereka mengalami kesulitan untuk mendapatkan rincian atas isi verbalitas sebagai inti dari latihan imagery. Namun gambaran mental tidak hanya perilaku spontan dari individu untuk membayangkan sesuatu penampilan. Selanjutnya, (Munzert, Zentgraf, Strak, et al, 2008) bahwa gerakan imagery adalah proses melalui sebuah observasi gerakan di bawah intruksi pikiran, yang kemudian salah satunya dapat menampilkan gerakan imagery dari pandangan orang pertama.

2. Model Latihan Imagery

Pada pelaksanaannya (Komarudin, 2015: 93) menjelaskan mengenai latihan imagery dapat dilakukan dengan cara duduk sejenak dan diikuti dengan menutup mata, usahakan relaks terlebih dahulu, lalu bernapaslah dalam-dalam beberapa kali usahakan membayangkan atau membuat imajinasi satu per satu pengalaman yang berhubungan dengan pancaindra lalu atlet dilatih untuk membuat khayalan-khayalan mental mengenai suatu gerakan atau keterampilan tertentu dengan membuat cognitive images. Dengan cara menyuruh atlet untuk melihat dan mengamati, memperhatikan, dan membanyangkan dengan seksama pola gerak tertentu.

(Heny Setyawati, 2014) menambahkan di dalam penelitiannya bahwaimagery sering disebut dengan guided imagery, visualization, latihan mental, atau self hypnosis. Imagery adalah teknik yang biasa digunakan oleh psikolog olahraga untuk membantu seseorang memvisualisasikan atau melatih mental berkaitan dengan kegiatan yang akan dilakukan, dalam konteks olahraga imagery digunakan untuk membantu atlet membuat visualisasi yang lebih nyata berkaitan dengan pertandingan atau kompetisi yang akan dijalaninya.

\section{Floating Service}

Floating Service merupakan salah satu servis yang dikembangkan dikarenakan kesukaran lawan dalam menerima servis terletak pada sifat jalannya bola yang mengapung, serta jalannya bola pada lintasan lurus, kecepatan yang tidak teratur, bola sering melayang ke kiri dan ke kanan. (Dieter
Beutelstahl 1986: 14) Floating Service adalah jenis servis yang tidak mengandung spin. Bola seakan akan melayang, tanpa beputar sama sekali. Servis ini cukup efektif, karena arah lajunya bola tidak menentu, bola itu bervibrasi kadang-kadang berubah arah vertikal maupun horisontal. Dengan demikian tingkat kesulitan dalam melakukan floating service lebih tinggi jika dibandingkan dengan servis normal. Selain membutuhkan teknik servis yang baik, dibutuhkan pula mental dan kepercayaan diri seorang atlet.

4. Voli Pantai

Voli pantai merupakan suatu permainan bola voli yang dilakukan oleh 2 orang per teamnya, semua teknik dasar dalam voli pantai hampir sama secara keseluruhan dengan voli indoor, yang membedakan adalah lokasi bermain di pasir/pantai dan sedikit peraturan dalam permainannya. Kiraly \& Shewman, (1999: 4) voli pantai atau voli pasir pertama kali muncul 25 tahun setelah permainan bola voli indoor atau voli lapangan, yaitu sekitar tahun 1915 dan pertama kali dimainkan di Hawaii, namun olahraga voli pantai ini populer di California pada tahun 1920. Kompetisi antar klub di California pada tahun 1924 sekaligus menandai terlaksananya turnamen voli pantai pertama. Pada saat itu voli pantai atau voli pasir masih sama dengan pemain voli indoor dengan jumlah pemain 6 orang setiap teamnya, lalu berkembang menjadi 3, lalu 4 dan menjadi 2 orang setiap teamnya.

Smith, (2006: 19) voli pantai merupakan tantangan khusus yang hadir untuk atlet, karena kurangnya kemampuan atlet untuk menghasilkan stabilitas tubuh dan kemampuan menggunakan tiga mekanisme perpanjangan otot tungkai (perpanjangan sendi pergelangan kaki, lutut, dan pinggul) untuk mendorong tubuh lebih efisien dalam melakukan reaksi di atas pasir. Oleh karena itu, peningkatan kualitas kebugaran kondisi fisik pada pemain bola voli professional mutlak dilakukan, (Marquez et al, 2009).

\section{Metode Penelitian}

Penelitian ini menggunakan metode penelitian dan pengembangan atau yang sering disebut research and development yang mana digunakan untuk menghasilkan sebuah produk yang diinginkan. Metode research and 
development merupakan metode penelitian yang digunakan untuk menghasilkan produk tertentu yang didahului oleh penelitian yang bersifat analisis kebutuhan dan untuk menguji keefektifan produk supaya dapat berfungsi di masyarakat luas, maka diperlukan penelitian untuk menguji keefektifan produk tersebut (Sugiyono, 2011: 297). Sejalan dengan pendapat teori research and development maka penelitian ini dilakukan untuk menghasilkan sebuah model latihan imageryuntuk meningkatkan ketepatan floating service.

Borg dan Gall (2003), model penelitian dan pengembangan memiliki sepuluh langkah pelaksanaan penelitian sebagai berikut : (1) studi pendahuluan dan pengumpulan data (kajian pustaka, pengamatan lapangan, membuat kerangka kerja penelitian), (2) perencanaan (tujuan penelitian, dana, waktu, prosedur penelitian, berbagai bentuk partisipasi, (3) mengembangkan produk awal (perencanaan draft awal produk), (4) ujicoba awal (mencoba draft produk ke wilayah dan subjek yang terbatas), (5) revisi untuk menyusun produk utama, (6) uji coba lapangan utama (uji coba ke wilayah dan subjek yang lebih luas), (7) revisi untuk menyusun produk operasional, (8) uji coba produk operasional (uji efektif produk), (9) revisi produk final (revisi produk yang efektif), dan (10) diseminasi dan implementasi produk hasil pengembangan (tujuannya agar produk yang baru saja dikembangkan dapat dipakai secara luas oleh pelaku olahraga, para pengajar di usia dini, dan masyarakat).

\section{Teknik dan Instrument Pengumpulan Data}

\section{Teknik Pengumpulan Data}

Penelitian dan pengembangan ini menggunakan instrumen yang disusun oleh peneliti berupa panduan analisis kebutuhan yang dikemas dalam wawancara, kuesioner obeservasi sistematik pada uji skala kecil dan skala besar dan lembar penilaian atlet. Kemudian ketiga instrumen penilaian akan dinilai oleh para ahli dan pelatih voli pantai. Ujicoba lapangan baik uji skala kecil maupun skala besar, pedoman yang digunakan untuk mengungkap pendapat dari para expert judgement adalah pedoman yang sama. Selanjutnya pada uji skala kecil dan skala besar diambil pula data kuesioner kepada atlet voli pantai yang menjadi subjek uji coba. Pengambilan pendapat dari atlet voli pantai dapat membantu perbaikan kualitas dari model latihan fundamental voli pantai khususnya pada floating service. Untuk tahap pasca pengembangan adalah uji efektifitas produk akhir yang sudah menjadi produk pengembangan final. Produk akhir diuji efektifitas dengan penerapan langsung di lapangan kepada atlet voli pantai NTB.

2. Instrument Pengumpulan Data

Penggunaan instrumen dalam penelitian pengembangan ini sebelum digunakan untuk mengambil data, maka harus melalui validasi instrumen dengan tujuan hasil data yang diperoleh valid dan realiabel. Validator instrumen dalam penelitian ini melibatkan para ahli istrumen. Selanjutnya instrumen yang sudah valid itu dapat digunakan dalam membuat analisis kebutuhan, instrumen untuk membuat draf model, uji coba produk dan instrumen keefektifan model. Instrumen yang digunakan dalam penelitian pengembanagn ini di validasi sebelum digunakan untuk mengambil data di lapangan.

\section{Teknik Analisis Data}

Teknik analisis data dalam penelitian pengembangan ini sebagai adalah:

1. Analisis Validitas dan Reliabilitas Instrument

Analisis vakiditas dan reliabilitas instrument menggunakan Formula Aikens'V. Aiken (1985) merumuskan formula Aiken's V untuk menghitung content validity coefficient yang didasarkan pada hasil penilaian dari panel ahli sebanyak $\mathbf{n}$ orang terhadap suatu item dari segi sejauh mana item tersebut mewakili konstrak yang diukur. Formula yang diajukan oleh Aiken adalah sebagai berikut (dalam Azwar, 2012: 113).

$$
\begin{array}{ll}
\boldsymbol{V} & =\boldsymbol{\Sigma} \boldsymbol{s} /[\boldsymbol{n}(\boldsymbol{c}-\mathbf{1})] \\
S & =r-\text { lo } \\
\text { Lo } & =\text { penilaian validitas yang terendah }(1) \\
C & =\text { penilaian validitas tertinggi }(4) \\
R & =\text { angka yang diberikan oleh penilai/ahli } \\
(\text { skor }) & \\
N & =\text { jumlah sampel }
\end{array}
$$

2. Analisis kelayakan (validitas) draft awal produk

Validasi draf awal produk menggunakan instrumen skala penilaian sebagai bahan panduan dalam menilai model 
latihan imagery untuk meningkatkan ketepatan floating service pada atlet voli pantai NTB. Berdasarkan penilaian dari para ahli materi terhadap skala nilai, terlihat bahwa total nilai draf awal model latihan imagery telah memenuhi persyaratan kelayakan untuk di uji cobakan di lapangan.

Penelitian pengembangan ini berupa draf awal latihan imagery dianggap layak untuk diujicobakan sebelum skala kecil maupun skala besar, apabila para ahli materi telah memberikan validasi dan menyatakan minimal tingkat validitas yang dicapai dalam kategori sesuai. Ernawatiningtyas (2015: 7), sebagai berikut:

\section{$P=f / N x(100 \%)$}

Keterangan:

$P \quad=$ frekuensi relatiflangka persentase yang dicari persentasenya

$F \quad=$ frekuensi (jumlah skor penilaian)

$N=$ jumlah seluruh data (butir soal)/skor maksimal

$100 \%=$ konstanta

Setelah persentase kelayakan didapat, dan produk dikatakan layak bilamana persentase kelayakan lebih dari 75\% (>75\%) atau disebut layak. Dalam hal ini terdapat 4 kategori kelayakan sesuai persentase kelayakan, yaitu layak, cukup layak, kurang layak dan tidak layak.

\begin{tabular}{|c|c|}
\multicolumn{2}{|c|}{ [Tabel 1, Klasifikasi kelayakan } \\
\hline Skor Nilai & Keterangan \\
\hline$>75 \%-100 \%$ & Layak \\
\hline$>50 \%-75 \%$ & Cukup layak \\
\hline$>25 \%-50 \%$ & Kurang layak \\
\hline$<25 \%$ & Tidak layak \\
\hline
\end{tabular}

\section{Analisis Observasi Model}

Pada analisis model terdapat dua data dari dua instrumen yaitu data yang dihasilkan dari hasil observasi model yang diberikan oleh para ahli dan praktisi. Analisis yang dilakukan adalah dengan hasil penilaian terhadap item-item observasi dijumlahkan, lalu diambil rerata nilainya dikonversikan untuk mengetahui kategorinya. Berdasarkan skala yang dipakai dalam pengkorversian menggunakan skala empat maka yang dipakai dalam perhitungan normatif menggunakan empat kategori yaitu tidak sesuai, cukup sesuai, sesuai, dan sangat sesuai yang akan dipaparkan pada model latihan imagery.

\section{Hasil Penelitian Dan Pembahasan}

\section{Hasil Analisis Kebutuhan}

Berdasarkan hasil analisis kebutuhan di lapangan yang dilakukan dengan metode observasi dan wawancara kepada pelatih voli pantai maka didapatkan informasi sebagai berikut:

a. Program latihan dasar yang khusus untuk melakukan floating sevice masih belum maksimal dilakukan oleh para atlet karena metode latihan yang konstan dan alokasi waktu yang kurang efisien dalam penerapan latihan

b. Program latihan yang disusun oleh pelatih masih didominasi pada aspek latihan fisik, teknik dan taktik daripada mengeksplorasi latihan fundamental dari floating service yang merupakan serangan utama dalam permainan bola voli

c. Metode latihan imagery yang difokuskan untuk meningkatkan aspek psikologis atlet masih belum diterapkan oleh para pelatih

d. Proses evaluasi yang dilakukan pelatih masih mendeskripsikan secara umum kemampuan para atlet tanpa menelaah latihan-latihan fundamental yang bisa meningkatkan motivasi atlet dalam melakukan latihan maupun pertandingan.

2. Deskripsi Draft Awal Produk

Pembuatan draft awal produk harus sesuai dengan analisis kebutuhan di lapangan, dalam penelitian ini produk yang akan dikembangkan berupa model latihan imagery terhadap ketepatan floating service, maka langkah selanjutnya adalah mendeskripsikan draft produk awal yang berisi keseluruhan dari tahapan-tahapan latihan imagery yang akan diterapkan pada ketepatan floating service.

3. Data Masukan dari Ahli dan Praktisi

Draf awal latihan imagery terhadap ketepatan floating service sebagai latihan atlet voli pantai yang di berikan kepada ahli materi. Adapun ahli materi adalah orang yang expert dalam bidangnya, dalam penelitian ini adalah: a) ahli psikologi olahraga, b) ahli bola voli, dan c) praktisi dari pelatih voli pantai NTB.

4. Revisi Draft Awal Produk

Draf yang sudah dibuat selanjutnya berdasar masukan di perbaiki guna 
penyempurnaan model latihan imagery. Draf yang sudah mendapat validasi draf dari ahli materi, maka model boleh di ujicobakan di lapangan, sebelum mendapat validasi maka draf terlebih dahulu di revisi sesuai dengan arahan dan masukan dari ahli materi. Hasil dari revisi draf awal model latihan imagery selanjutnya diajukan untuk mendapatkan validasi draf model. Dalam mengajukan validasi draf awal model menggunakan instrumen skala penilaian sebagai bahan panduan dalam menilai model latihan imagery untuk meningkatkan ketepatan floating service pada atlet voli pantai NTB.

5. Validasi Isi Instrument

Sebelum instrumen yang digunakan dalam mengambil data baik yang digunakan dalam observasi draf awal, observasi skala kecil, observasi skala besar dan juga observasi efektivitas produk, maka semua instrumen di validasi untuk mengetahui validitas isi alat ukur yang akan digunakan dalam penelitian ini.

Validasi ini menggunakan formula Aiken's V untuk menghitung content validity coefficient yang didasarkan pada hasil penilaian dari panel ahli sebanyak $\mathbf{n}$ orang terhadap suatu item dari segi sejauh mana item tersebut mewakili konstrak yang diukur.

\section{Validitas Draf Awal Produk}

Penelitian pengembangan ini berupa draf awal latihan imagery dianggap layak untuk diujicobakan sebelum skala kecil maupun skala besar, apabila para ahli materi telah memberikan validasi dan menyatakan minimal tingkat validitas yang dicapai dalam kategori sesuai. Berikut hasil validasi dari para ahli materi dan praktisi:

Tabel 2. Data rekapitulasi draft awal produk dari para ahli

\begin{tabular}{|l|c|c|c|}
\hline $\begin{array}{c}\text { Ahli } \\
\text { materi }\end{array}$ & Skor & $\begin{array}{c}\text { Nilai } \\
\text { max }\end{array}$ & $\begin{array}{c}\text { Persentase } \\
\text { kelayakan }\end{array}$ \\
\hline Ahli 1 & 61 & 72 & 84 \\
\hline Ahli 2 & 65 & 72 & 91 \\
\hline Ahli 3 & 56 & 72 & 77 \\
\hline
\end{tabular}

Pada ahli pertama dihasilkan total skor 61 dan nilai maksimal 72 dari 18 item. Sedangkan persentase kelayakan sebesar $84 \%$ dengan menggunakan batas minimal dikatakan layak adalah $>75 \%$. Maka penilaian ahli pertama terhadap model latihan imagery dikatakan 'layak' karena $84 \%>75 \%$. Pada ahli kedua dihasilkan total skor 65 dan nilai maksimal 72 dari 18 item. Sedangkan persentase kelayakan sebesar $91 \%$ dengan menggunakan batas minimal dikatakan layak adalah $>75 \%$. Maka penilaian ahli kedua terhadap model latihan imagery dikatakan 'layak' karena $91 \%>75 \%$. Pada ahli ketiga dihasilkan total skor 56 dan nilai maksimal 72 dari 18 item. Sedangkan persentase kelayakan sebesar $77 \%$ dengan menggunakan batas minimal dikatakan layak adalah $>75 \%$. Maka penilaian ahli ketiga terhadap model latihan imagery dikatakan 'layak' karena $77 \%$ > $75 \%$.

7. Uji Coba Skala Kecil

Hasil dari uji skala kecil yang didapatkan pada ahli pertama dihasilkan total skor 30 dan nilai maksimal 36 dari 9 item. Sedangkan persentase kelayakan sebesar $83.3 \%$ dengan menggunakan batas minimal dikatakan layak adalah $>75 \%$. Maka penilaian ahli pertama terhadap model latihan imagery dikatakan 'layak' karena $83.3 \%>75 \%$. Pada ahli kedua dihasilkan total skor 29 dan nilai maksimal 36 dari 9 item. Sedangkan persentase kelayakan sebesar $80.5 \%$ dengan menggunakan batas minimal dikatakan layak adalah $>75 \%$. Maka penilaian ahli kedua terhadap model latihan imagery dikatakan 'layak' karena $80.5 \%$ > $75 \%$. Pada ahli ketiga dihasilkan total skor 32 dan nilai maksimal 36 dari 9 item. Sedangkan persentase kelayakan sebesar $88.8 \%$ dengan menggunakan batas minimal dikatakan layak adalah $>75 \%$. Maka penilaian ahli ketiga terhadap model latihan imagery dikatakan 'layak' karena $88.8 \%>75 \%$.

8. Uji Coba Skala Besar

Hasil dari uji skala besar yang didapatkan pada ahli pertama dihasilkan total skor 34 dan nilai maksimal 36 dari 9 item. Sedangkan persentase kelayakan sebesar $94.4 \%$ dengan menggunakan batas minimal dikatakan layak adalah $>75 \%$. Maka penilaian ahli pertama terhadap model latihan imagery dikatakan 'layak' karena $94.4 \%>75 \%$. Pada ahli kedua dihasilkan total skor 33 dan nilai maksimal 36 dari 9 item. Sedangkan persentase kelayakan sebesar $91.6 \%$ dengan menggunakan batas minimal dikatakan layak adalah $>75 \%$. Maka penilaian ahli kedua terhadap model latihan 
imagery dikatakan 'layak' karena 91.6\% > $75 \%$. Pada ahli ketiga dihasilkan total skor 34 dan nilai maksimal 36 dari 9 item. Sedangkan persentase kelayakan sebesar $94.4 \%$ dengan menggunakan batas minimal dikatakan layak adalah $>75 \%$. Maka penilaian ahli ketiga terhadap model latihan imagery dikatakan 'layak' karena $94.4 \%>75 \%$.

\section{Kesimpulan dan Saran}

Kesimpulan

Berdasarkan kesimpulan dari hasil pengembangan produk di atas menunjukkan bahwa model latihan imagery ini dikembangkan dengan metode pengembangan dengan 10 langkah dan diadopsi menjadi 7 tahap sesuai dengan kebutuhan penelitian ini, dalam penelitian yang dilakukan didapatkan bahwa permasalahan yang selama ini dihadapi dalam program latihan atlet voli pantai, yaitu belum adanya penerapan latihan fundamental khususnya floating service yang menggunakan ranah psikologi, dalam hal ini adalah latihan imagery. Berdasarkan dari hasil penelitian uji skala kecil dan skala besar yang telah dilakukan dengan percobaaan floating service dinyatakan bahwa penilaian para ahli terhadap model latihan imagery untuk meningkatkan ketepatan floating service dikatakan 'layak' untuk diterapkan di lapangan.

\section{SARAN}

Saran untuk pemanfaatan produk yang telah dihasilkan dari pengembangan model latihan imgery pada ketepatan floating service atlet voli pantai NTB adalah:

1. Dapat digunakan oleh pelatih sebagai variasi latihan psikologis atlet untuk meningkatkan ketepatan floating service.

2. Memberikan pelatih tambahan referensi dalam melatih aspek psikologis atlet.

3. Model latihan imagery yang dihasilkan diharapkan mampu memberikan motivasi kepada atlet dalam meningkatkan latihannya.

\section{Daftar Pustaka}

Aiken, L. R. (1985). Three coefficients for analyzing the reliability, and validity of ratings. Educational and Psychological Measurement, 45, 131-142.

Azwar, S. (2012). Reliabiltas dan validitas. Edisi 4. Yogyakarta: Pustaka Pelajar.
Beutalstahl, Dieter. (1986). Belajar bermain bola voli. Pioner Jaya: Bandung.

Ernawatiningtyas,

B. Mengembangakan kemampuan motorik halus melalui kegiatan menggambar dengan media pemberian contoh-contoh gambar variatif. Artikel Penelitian: Universitas Nusantara PGRI Kediri, hal. $1-11$.

Gall, M.D., Joyce, P., \& Borg, W.R. (2003). Educational research. Longman, New York.

Hardy, L., Jones, G., \& Gould, D. (1996). Understanding psychological preparation for sport: theory and practice of elite performers. Wiley, Chichester.

Heny Setyawati. (2014). Strategi intervensi peningkatan rasa percaya diri melalui imagery training pada atlet wushu jawa tengah. Journal of physical education.

Holmes, P. \& Collins, D. (2001). The PETTLEP approach to motor imagery.A functional equivalence model for sport psychologists. Journal of Applied Sport Psychology, 13, 60-83.

Kiraly, K., \& Shewman, B. (1999). Beach volleyball. Champaign, IL: Human Kinetics.

Komarudin. (2013). Psikologi olahraga. Bandung: PT. Remaja Rosdakarya.

Marques, M.C., van den Tillar, R., Gabbett, T.J., Reis, V.M., \& Gonzales-Badillo, J.J. (2009). Physical fitness qualities of professional volleyball players: determination of positional differences. Journal of Strength and Conditioning Research. ProQuest Nursing \& Allied Health Source pg. 1106.

Ma'mun, A. dan Subroto, T. (2001). Pendekatan keterampilan taktis dalam pembelajaran bola voli. Jakarta: Direktoral Jendral Olah Raga.

Morris, T,. Spittle, M,. And Watt, A. (2005). Imagery in sport. shool of human movement, recreation, and performance and centre for ageing, rehabililation, exercise and sport. Victoria University: Human Kinetics.

Munzert, J., Zentgraf, Z., Strak, R., et al. (2008). Neural activation in cognitive motor processes: comparing motor 
imagery and observation of gymnastic movements. Springer, 188, 437-444.

Smith, Robert. (2006). Movement in the sand: training implications for beach volleyball. Strength and Conditioning Journal. ProQuest Nursing \& Allied Health Source pg. 19.

Sugiyono. (2011). Metode penelitian pendidikan pendekatan kuantitatif, kualitatif dan $R \& D$. Bandung: Alfabeta.

Sukadiyanto. (2011). Pengantar teori dan metodologi melatih fisik. Bandung: Lubuk Agung.

Taylor, J., \& Wilson, G. (2005). Applying sport psychology: four perspectives. Champaign, IL: Human Kinetics.

Yunus, M. (1992). Olahraga pilihan bola voli. Jakarta: Depdikbud. 